\title{
ЗАСТОСУВАННЯ СУХОГО ЕКСТРАКТУ З ЛИСТЯ ХОСТИ ЛАНЦЕТОЛИСТОЇ ДЛЯ КОРЕКЦІЇ МЕТАБОЛІЧНИХ ПОРУШЕНЬ ЗА УМОВ АДРЕНАЛІНОВОГО УРАЖЕННЯ МІОКАРДА
}

Вступ. Однією з особливостей розвитку серцевих захворювань $є$ активація процесів пероксидного окиснення ліпідів, збільшення кількості прооксидантних процесів, що є наслідком впливу на живу систему гемодинамічних порушень і спричинених ними гіпоксичних явищ. Для лікування захворювань серцево-судинної системи використовують рослинні препарати на основі речовин фрлавоноїдної природи, які мають широкий спектр активності. Застосування лікарських засобів на основі даних речовин зумовлене вираженими антирадикальними властивостями.

Мета дослідження - встановити антиоксидантні та мембранопротекторні властивості сухого екстракту з листя хости ланцетолистої на моделі ураження міокарда токсичними дозами адреналіну.

Методи дослідження. Дослідження виконано на білих щурах-самцях, яким моделювали некротичне ушкодження міокарда шляхом введення 0,18 \% розчину адреналіну гідротартрату з розрахунку 0,5 мг/к己 маси тіла. Одній із груп тварин, уражених адреналіном, вводили сухий екстракт з листя хости ланцетолистої в дозі 100 мг/ке маси тіла, іншій - кардіопротектор корвітин у дозі 42 мг/кг маси тіла. У сироватці крові визначали вміст ТБК-активних продуктів, активність аспартатамінотрансорерази та креатинфроссрокінази, активність супероксиддисмутази і вміст церулоплазміну, в міокарді - вміст ТБК-активних продуктів та вищеназвані органоспецифрічні ензими.

Результати й обговорення. Встановлено, що введення адреналіну в дозі 0,5 мг/кг маси тіла призводило до активації процесів пероксидного окиснення ліпідів у міокарді та сироватці крові щурів, на що вказувало збільшення вмісту ТБК-активних продуктів протягом 48 год від початку експерименту. Водночас відмічали зниження в сироватці крові активності супероксиддисмутази та підвищення вмісту церулоплазміну, що свідчило про глибокі порушення в ензимній ланці антиоксидантної системи. Дослідження активності аспартатамінотрансферази в щурів, уражених адреналіном, показало ї̈ростання в сироватці крові у всі терміни дослідження та зниження в міокарді. Аналогічні зміни відзначено при вивченні активності креатинсроссрокінази у тварин після розвитку адреналінової кардіопатії. Застосування сухого екстракту з листя хости ланцетолистої мало ефективний вплив на про- та антиоксидантні показники в щурів після ураження, а також привело до нормалізації активності органоспецифрічних ензимів міокарда.

Висновок. Сухий екстракт з листя хости ланцетолистої проявляє антиоксидантні властивості за умов адреналінової кардіопатії, що може бути передумовою для подальших експериментальних досліджень даного лікарського засобу.

КЛЮЧОВІ СЛОВА: адреналінове ураження міокарда; сухий екстракт з листя хости ланцетолистої; окиснювальні процеси; антиоксидантна система; органоспецифічні ензими.

ВСТУП. У соціально-економічних умовах, які відзначаються широким спектром нестабільності, морального та психічного навантаження, що переживає Україна впродовж останнього десятиріччя, значно поширився вплив стресових чинників на виникнення серцевої патології $[1,2]$. Найбільшу роль у цій патології відіграють некротичні ураження серцевого м'яза, що розвиваються внаслідок невідповідності між потребами міокарда в кисні та доставкою його коронарними (с О. С. Линда, Л. С. Фіра, П. Г. Лихацький, 2018. судинами, а також хвороби міокарда, зумовлені порушенням метаболізму в серцевому м'язі, міокардіодистрофрії [3, 4].

В експерименті моделі дистрофрічно-некротичних уражень міокарда викликають шляхом створення різних стресових ситуацій (фрізичний, емоційний, іммобілізаційно-больовий стреси), а також введення кардіотоксичних доз катехоламінів [5-8]. Будь-які стресорні чинники, незалежно від їх природи, спричиняють підвищене продукування ендогенних катехоламінів. 
Однією з особливостей розвитку серцевих захворювань $€$ активація процесів пероксидного окиснення ліпідів, збільшення кількості прооксидантних процесів, що є наслідком впливу на живу систему гемодинамічних порушень і спричинених ними гіпоксичних явищ [9]. При некротичному ушкодженні міокарда основним фрактором, який визначає його ступінь, є величина зони некрозу, активність мембраноруйнівних процесів та імунних реакцій.

На фоні бурхливого розвитку хімічної промисловості та появи в медичному арсеналі нових синтетичних лікарських засобів з кожним роком дедалі більшим попитом користуються препарати рослинного походження. Вони містять комплекси біологічно активних речовин, що близькі за своєю структурою до метаболітів організму людини, оптимально сумісні 3 ним, мають нижчі токсичність і алергенність порівняно із синтетичними сполуками [10]. Лікарські рослини в останні роки зайняли надійні позиції в традиційній медицині, маючи безперечні переваги (спорідненість хімічної природи фрітопрепаратів до організму людини; широкий спектр біологічної дії тощо).

Широкий спектр активності мають рослинні препарати на основі речовин фрлавоноїдної природи. Застосування лікарських засобів на основі даних речовин зумовлене вираженими антирадикальними властивостями [11].

3 огляду на вищесказане, мета даного дослідження-встановити антиоксидантні та мембранопротекторні властивості сухого екстракту 3 листя хости ланцетолистої на моделі ураження міокарда токсичними дозами адреналіну.

МЕТОДИ ДОСЛІДЖЕННЯ. Дослідження виконано на 42 білих щурах-самцях, яких утримували на стандартному раціоні віварію Тернопільського державного медичного університету імені І. Я. Горбачевського.

Некротичне ушкодження міокарда моделювали шляхом одноразового внутрішньом'язового введення щурам 0,18 \% розчину адреналіну гідротартрату (ЗАТ “Фармацевтична срірма "Дарниця", м. Київ, Україна) з розрахунку 0,5 мг/кг за методикою О. О. Маркової [5]. Було обрано найнижчу кардіонекрозогенну дозу адреналіну 0,5 мг/кг для уникнення високої смертності піддослідних тварин.

При вивченні кардіопротекторної та антиоксидантної активності сухого екстракту з листя хости ланцетолистої (СЕХЛ) як препарат порівняння використовували "Корвітин" (виробництва ЗАТ НВЦ "Борщагівський хіміко-срармацевтичний завод", м. Київ, Україна) - напівсинтетичний лікарський засіб з антиоксидантною активністю, який вводили внутрішньовенно (у хвостову вену). Значення дози препарату порівняння обирали, спираючись на інструкцію до застосування та використовуючи коефріцієнти видової чутливості Ю. Р. Риболовлєва ійого метод перерахунку дози для людини на дозу для щура [12]. Умовно-терапевтична доза для щура становить 42 мг/кг.

Для проведення відповідних досліджень щурів було поділено на 4 групи: 1-ша - контрольні тварини (інтактні); 2-га - тварини, уражені $0,18 \%$ розчином адреналіну гідротартрату (одноразово), шлях введення - внутрішньом'язово; 3-тя - тварини, уражені адреналіном та ліковані сухим екстрактом з листя хости ланцетолистої в дозі 100 мг/кг маси тіла, шлях введення - інтрагастрально; 4-та - тварини, уражені адреналіном та ліковані корвітином у дозі 42 мг/кг маси тіла, шлях введення - внутрішньовенно.

Евтаназію тварин проводили з використанням тіопентал-натрію через 24 та 48 год від початку введення адреналіну.

Для досліджень обрали сироватку крові та міокард щурів.

Активність процесів ліпопероксидації оцінювали за вмістом ТБК-активних продуктів (ТБК-АП) [13], активність антиоксидантної системи - за активністю супероксиддисмутази [14] та вмістом церулоплазміну (ЦП) [15]. Для оцінки фрункціонального стану цитоплазматичних мембран кардіоцитів визначали активність аспартатамінотрансорерази (АсAТ) [16] та креатинсроссрокінази (КФК) [17].

Дослідження проводили згідно із Загальними принципами експериментів на тваринах, узгодженими з положеннями Європейської конвенції про захист хребетних тварин, що використовуються для дослідних та інших наукових цілей [18].

Результати досліджень піддавали статистичному аналізу [19] за допомогою статистичної програми STATISTICA 6.0 з використанням параметричного критерію Стьюдента і непараметричного критерію Вілкоксона для зв'язаних вибірок. Зміни вважали достовірними при $p \leq 0,05$.

РЕЗУЛЬТАТИЙ ОБГОВОРЕННЯ. ВИНИКНЕННЯ метаболічних порушень у фуннціонуванні серцево-судинної системи пов'язують з утворенням вільних радикалів, які особливо негативно впливають на фуннкцію та структуру мембран кардіоміоцитів. Саме активація вільнорадикального окиснення $є$ одним із провідних патогенетичних механізмів ураження серця адреналіном [20].

Встановлено, що введення адреналіну в дозі 0,5 мг/кг маси тіла призводило до активації процесів пероксидного окиснення ліпідів у міокарді та сироватці крові щурів. Про розвиток окисню- 
вальних процесів в ураженому організмі судили за вмістом ТБК-АП. Результати досліджень наведено в таблиці 1.

У сироватці крові через 48 год з моменту ураження щурів адреналіном вміст ТБК-АП збільшився на 97 \%, у міокарді - на 142 \%. Після застосування сухого екстракту з листя хости ланцетолистої даний показник знизився на 70 \% у сироватці крові, після корекції корвітином він практично досягнув рівня інтактних тварин.

Ефективним виявилось застосування обох коригувальних чинників при дослідженні вмісту продуктів ліпопероксидації в міокарді уражених щурів. Введення в уражений організм сухого екстракту з листя хости ланцетолистої призвело до вірогідного $(p \leq 0,05)$ зменшення вмісту ТБК-АП у міокарді тварин, уражених адреналіном. У кінці експерименту даний показник знизився на $84 \%$. Більш ефективним виявився корвітин, хоча рівня норми вміст ТБК-АП у міокарді після його застосування ще не досягнув.

Використання сухого екстракту з листя хости ланцетолистої призвело до зниження активності процесів ліпопероксидації, що дозволило підтвердити передбачувані антиоксидантні властивості даного фрармакологічного засобу, зумовлені наявністю в листі рослини значної кількості фенольних сполук, органічних кислот і вітамінів.

Активація вільнорадикальних процесів в організмі піддослідних тварин при потраплянні токсичних доз адреналіну супроводжується порушенням фрункціонування ензимних і неензимних антиоксидантів, що пов'язано як із виснаженням їх резервів у зв'язку з інтенсивним споживанням у реакціях детоксикації, так і 3 порушенням синтезу [20].

Ураження серця адреналіном супроводжується зниженням у сироватці крові активності одного 3 наймогутніших ензимів антиоксидантного захисту - супероксиддисмутази. Активність ензиму через 24 год від початку розвитку кардіопатії у крові щурів становила 72 \% від рівня інтактного контролю, через 48 год - 61 \% (табл. 2).

Сухий екстракт з листя хости ланцетолистої мав позитивний вплив на даний показник, і активність ензиму до кінця експерименту збільшилась на 27 \% порівняно з ураженими тваринами. Після застосування корвітину цей показник досягнув рівня норми і становив 98 \% відносно рівня інтактного контролю.

Після ураження міокарда токсичними дозами адреналіну в сироватці крові щурів відзначали прогресуюче зростання вмісту ЦП (через 24 год від початку ураження він збільшився в 1,4 раза, через 48 год - був в 1,5 раза вищим від норми), що свідчило про активне включення даного протеїну в процес знешкодження вільних радикалів уже на початкових стадіях вільнорадикального окиснення (табл. 2).

Через 24 год від моменту ураження міокарда адреналіном та застосування екстракту з хости ланцетолистої відмічали тенденцію до зменшення вмісту ЦП, але вірогідних змін не спостерігали. До кінця дослідження даний показник зазнав вірогідного зниження, наближаючись до норми. Корвітин виявився есрективним щодо вмісту ЦП у сироватці крові уражених тварин в обидва терміни дослідження.

Таблиця 1 - Вміст ТБК-активних продуктів у сироватці крові (мкмольл) та міокарді (мкмоль/кг) щурів, уражених адреналіном, після введення екстракту з листя хости ланцетолистої та корвітину $(\mathrm{M} \pm \mathrm{m}, \mathrm{n}=42)$

\begin{tabular}{|l|c|c|c|c|}
\hline \multirow{2}{*}{\multicolumn{2}{|c|}{ Група тварин }} & \multicolumn{2}{c|}{ Сироватка крові } & \multicolumn{2}{c|}{ Міокард } \\
\cline { 2 - 5 } & \multicolumn{3}{|c|}{ термін дослідження, год } \\
\cline { 2 - 5 } & 24 & 48 & 24 & 48 \\
\hline Контрольні & \multicolumn{2}{|c|}{$3,30 \pm 0,25$} & \multicolumn{2}{c|}{$0,95 \pm 0,06$} \\
\hline Уражені адреналіном & $6,20 \pm 0,42^{\star}$ & $6,50 \pm 0,45^{\star}$ & $2,10 \pm 0,16^{\star}$ & $2,30 \pm 0,17^{\star}$ \\
\hline Уражені+ліковані СЕХЛ, 100 мг/кг & $4,75 \pm 0,33^{\star \star}$ & $4,20 \pm 0,32^{\star \star}$ & $1,40 \pm 0,12^{\star \star}$ & $1,50 \pm 0,11^{\star \star}$ \\
\hline Уражені+ліковані корвітином, 42 мг/кг & $4,15 \pm 0,23^{\star \star}$ & $3,50 \pm 0,26^{\star \star}$ & $1,35 \pm 0,13^{\star \star}$ & $1,30 \pm 0,10^{\star \star}$ \\
\hline
\end{tabular}

Примітки. Тут і в таблицях 2-4:

1. * - вірогідні зміни між контрольними та ураженими тваринами $(p \leq 0,05)$.

2. ** - вірогідні зміни між ураженими та лікованими тваринами $(p \leq 0,05)$.

Таблиця 2 - Активність супероксиддисмутази (мкмоль/л) і вміст церулоплазміну (мг/л) у сироватці крові щурів, уражених адреналіном, після застосування коригувальних чинників ( $\mathrm{M} \pm \mathrm{m}, \mathrm{n}=42)$

\begin{tabular}{|c|c|c|c|c|}
\hline \multirow{3}{*}{ Група тварин } & \multicolumn{2}{|c|}{ СОД } & \multicolumn{2}{|c|}{ ЦП } \\
\hline & \multicolumn{4}{|c|}{ термін дослідження, год } \\
\hline & 24 & 48 & 24 & 48 \\
\hline Контрольні & \multicolumn{2}{|c|}{$32,5 \pm 2,1$} & \multicolumn{2}{|c|}{$10,2 \pm 0,7$} \\
\hline Уражені адреналіном & $23,4 \pm 1,7^{*}$ & $19,8 \pm 1,6^{*}$ & $14,3 \pm 0,6^{*}$ & $15,0 \pm 0,8^{*}$ \\
\hline Уражені+ліковані СЕХЛ, 100 мг/кг & $28,2 \pm 1,4$ & $28,7 \pm 1,3^{\star \star}$ & $12,3 \pm 0,8$ & $11,5 \pm 0,6^{\star \star}$ \\
\hline Уражені+ліковані корвітином, 42 мг/кг & $30,7 \pm 1,8^{* \star}$ & $32,0 \pm 1,7 * *$ & $10,8 \pm 0,6^{* \star}$ & $10,5 \pm 0,5^{\star *}$ \\
\hline
\end{tabular}


3 літератури відомо, що нормальне функціонування органів залежить від стану цитоплазматичних мембран клітин, зміна структури та фрункції яких порушує їх бар'єрну здатність і є причиною виникнення патологічних процесів. Зростання швидкості оновлення ензимів або індукування, ушкодження клітин призводять до підвищення їх активності в сироватці крові [21].

Рівень активності органоспецифрічних ензимів корелює зі ступенем вираження патологічного процесу в організмі уражених тварин. Тому для оцінки тканинодеструктивних процесів при ураженні тварин адреналіном було досліджено активність таких ензимів, як аспартатамінотрансорераза і креатиноросорокіназа, в сироватці крові та міокарді.

При вивченні активності АсАТ у сироватці крові щурів, уражених адреналіном, виявлено ії зростання у всі терміни дослідження (табл. 3).

При дослідженні сироватки крові уражених щурів встановлено зростання активності аспартатамінотрансорерази: на 49,8 \% - у термін 24 год, на 74,5 \% - у термін 48 год порівняно 3 інтактною групою. У групі тварин, яким вводили екстракт, даний показник був нижчим від такого в уражених: на 18,9 \% - через 24 год після ураження, на 24,4 \% -у кінці експерименту ( $p \geq 0,05)$. Більш ефективним виявився корвітин: до кінця дослідження активність АсАТ у сироватці крові уражених щурів після його застосування змен-

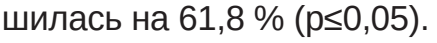

У міокарді уражених адреналіном тварин відмічали прогресуюче зниження активності АсАТ у всі терміни дослідження. У термін 48 год після введення адреналіну показник був меншим від норми на 31,25 \%.
Після введення в уражений організм сухого екстракту з листя хости ланцетолистої спостерігали підвищення активності досліджуваного ензиму, але вірогідних змін не відмічено. Застосування корвітину призвело до вірогідного зростання активності АсАТ у міокарді щурів після ураження.

Доцільним, на нашу думку, також було дослідити активність креатинсроссрокінази - ензиму, що локалізується в кардіоміоцитах і каталізує реакцію перенесення залишку фосоратної кислоти 3 АТФ на креатин $з$ утворенням креатинфроссрату, який $є$ енергетичним субстратом для серця [22].

Після введення адреналіну активність КФК у сироватці крові тварин значно зросла. Через 24 год після ураження вона збільшилась у 2,2 раза порівняно 3 контролем. Через 48 год від моменту потрапляння в організм адреналіну активність ензиму підвищилась у 2,5 раза (табл. 4).

Обидва коригувальних чинники призвели до зменшення активності КФК у сироватці крові (екстракт знизив досліджуваний показник в 1,6 раза, корвітин - в 1,8 раза відносно групи уражених тварин).

Активність КФК у міокарді уражених адреналіном тварин була низькою в усі терміни дослідження (табл. 4). Максимально низьку активність КФК відзначали в термін 48 год від моменту ураження (виявилась у 2 рази меншою від рівня норми). У термін 24 год після ураження до вірогідного підвищення даного показника в досліджуваній тканині призвело використання корвітину (активність КФК зросла в 1,4 раза).

У цей термін після застосування екстракту спостерігали тенденцію до підвищення актив-

Таблиця 3 - Активність аспартатамінотрансорерази в сироватці крові (мкмоль/(л·год)) та міокарді (мкмоль/(кг-год)) щурів, уражених адреналіном, після застосування коригувальних чинників ( $\mathrm{M} \pm \mathrm{m}, \mathrm{n}=42)$

\begin{tabular}{|c|c|c|c|c|}
\hline \multirow{3}{*}{ Група тварин } & \multicolumn{2}{|c|}{ Сироватка крові } & \multicolumn{2}{|c|}{ Міокард } \\
\hline & \multicolumn{4}{|c|}{ термін дослідження, год } \\
\hline & 24 & 48 & 24 & 48 \\
\hline Контрольні & \multicolumn{2}{|c|}{$2,75 \pm 0,20$} & \multicolumn{2}{|c|}{$3,20 \pm 0,17$} \\
\hline Уражені адреналіном & $4,12 \pm 0,32^{*}$ & $4,80 \pm 0,24^{*}$ & $2,55 \pm 0,13^{\star}$ & $2,20 \pm 0,12^{*}$ \\
\hline Уражені+ліковані СЕХЛ, 100 мг/кг & $3,60 \pm 0,25$ & $3,49 \pm 0,16^{\star \star}$ & $2,75 \pm 0,14$ & $2,45 \pm 0,13$ \\
\hline Уражені+ліковані корвітином, 42 мг/кг & $3,45 \pm 0,18$ & $3,10 \pm 0,17^{\star \star}$ & $3,12 \pm 0,15^{\star \star}$ & $2,85 \pm 0,14^{\star \star}$ \\
\hline
\end{tabular}

Таблиця 4 - Активність креатинфосфокінази в сироватці крові (мкат/л) та міокарді (мкат/кг) щурів,

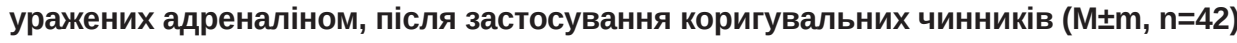

\begin{tabular}{|l|c|c|c|c|}
\hline \multirow{2}{*}{\multicolumn{2}{|c|}{ Група тварин }} & \multicolumn{2}{c|}{ Сироватка крові } & \multicolumn{2}{c|}{ Міокард } \\
\cline { 2 - 5 } & \multicolumn{3}{|c|}{ термін дослідження, год } \\
\cline { 2 - 5 } & 24 & 48 & 24 & 48 \\
\hline Контрольні & \multicolumn{2}{|c|}{$8,25 \pm 0,52$} & \multicolumn{2}{c|}{$9,50 \pm 0,55$} \\
\hline Уражені адреналіном & $18,50 \pm 1,25^{*}$ & $20,75 \pm 1,45^{\star}$ & $6,20 \pm 0,45^{\star}$ & $4,70 \pm 0,38^{\star}$ \\
\hline Уражені+ліковані СЕХЛ, 100 мг/кг & $14,25 \pm 0,84^{\star *}$ & $13,00 \pm 0,65^{\star *}$ & $7,25 \pm 0,33$ & $8,60 \pm 0,44^{\star *}$ \\
\hline Уражені+ліковані корвітином, 42 мг/кг & $12,45 \pm 0,75^{\star *}$ & $11,50 \pm 0,70^{\star *}$ & $8,60 \pm 0,43^{\star *}$ & $9,05 \pm 0,55^{\star *}$ \\
\hline \hline
\end{tabular}


ності ензиму, вірогідних змін не відмічали. У кінці експерименту ефективний вплив на даний показник мали обидва коригувальних чинники.

ВИСНОВКИ. Ураження щурів токсичними дозами адреналіну призводить до цитолізу кардіоцитів та зміни проникності плазматичних мембран, на що вказують підвищення активності аспартатамінотранссрерази і креатинсроссрокінази в сироватці крові та зниження її у міокарді.

Сухий екстракт з листя хости ланцетолистої проявляє антиоксидантні властивості за умов адреналінової кардіопатії, знижуючи рівень окиснювальних процесів в організмі щурів та відновлюючи активність антиоксидантної системи. Відмічені позитивні зміни активності мембранозалежних ензимів після його застосування можуть бути опосередкованими через прояв антиоксидантного ефекту даного фрармакологічного препарату.

Отримані дані $є$ передумовою для подальших експериментальних досліджень, що стосуються вивчення сухого екстракту з листя хости ланцетолистої, після чого його можна включати до загальних схем лікування серцево-судинних захворювань.

\section{СПИСОК ЛІТЕРАТУРИ}

1. Резолюція XVI Національного конгресу кардіологів України (Київ, 23-25 вересня 2015 р.) // Укр. кардіол. журн. - 2015. - № 5. - С. 126-130.

2. Фуштей И. М. Некоторые вопросы метаболической терапии при ишемической болезни сердца / И. М. Фуштей // Сучасні мед. технології. - 2010. № 3. - С. 111-116.

3. Кушаковский М. С. Метаболические болезни сердца (Миокардии-миокардозы-миокардиодистрофрии-кардиомиопатии) / М. С. Кушаковский. - СПб : Фолиант, 2000. - 128 с.

4. Sumitra M. Experimental myocardial necrosis in rats: role of arjunolic acid on plateled aggregation, coagulation and antioxidant status / M. Sumitra, P. Manikandan, D. A. Kumar // Mol. Cell. Biochem. 2001. - 224, No. 1-2. - P. 135-142.

5. Маркова О. О. Міокардіодистрофія і реактивність організму / О. О. Маркова. - Тернопіль : Укрмедкнига, 1998. - 152 с.

6. El-Sayed E. M. Thymol and carvacrol prevent doxorubicin-induced cardiotoxicity by abrogation of oxidative stress, inflammation, and apoptosis in rats / E. M. ElSayed, A. M. Mansour, M. S.Abdul-Hameed // J. Biochem. Mol. Toxicol. - 2015.

7. Kassim T. A. Catecholamine-induced cardiomyopathy / T. A. Kassim, D. D. Clarke, V. Q. Mai // Endocr. Pract. - 2008. - 14, No. 9. - P. 1137-1149.

8. Experimental model of myocardial infarction induced by isoproterenol in rats / H. G. Lobo Filho, N. L. Ferreira, R. B. Sousa // Rev. Bras. Cir. Cardiovasc. 2011. - 26, No. 3. - P. 232-237.

9. Активність вільнорадикальних процесів у щурів в умовах пошкодження міокарду адреналіном та при використанні сухого екстракту з листя абрикоса / А. Л. Штробля, Л. С. Фіра, Е. М. Вашкеба, Л. А. Бойко // Укр. біофрармац. журн. - 2012. - № 4. - С. 94-96.

10. Корсун В. Ф. Энциклопедия фритотерапии Травы жизни проф. Корсуна / В. Ф. Корсун, Е. В. Корсун. - М. : ЗАО Центрполиграфр, 2008. - 443 с.
11. Громовая В. Ф. Антиоксидантные свойства лекарственных растений / В. Ф. Громовая, Г. С. Шаповал, И. Е. Миронюк // Хим.-срармац. журн. - 2008. 42, № 3. - С. 26-29.

12. Рыболовлев Ю. Р. Дозирование веществ для млекопитающих по константам биологической активности / Ю. Р. Рыболовлев, Р. С. Рыболовлев // Докл. АН СССР. - 1979. - 247, № 6. - С. 1513-1516.

13. Лущак В. І. Показники оксидативного стресу. Тіобарбітурактивні продукти і карбонільні групи білків / В. І. Лущак, Т. В. Багнюкова, О. В. Лущак // Укр. біохім. журн. - 2004. - 26. - С. 136-141.

14. Чевари С. Роль супероксиддисмутазы в окислительных процессах и метод определения ее в биологическом материале / С. Чевари, И. Чаба, Й. Секей // Лаб. дело. - 1985. - № 11. C. 678-681.

15. Мжельская Т. И. Биологические функции церулоплазмина и их десрицит при мутации генов, регулирующих обмен меди и железа / Т. И. Мжельская // Бюлл. эксперим. биологии. - 2000. - 130, № 8. C. $124-133$

16. Колб В. Г. Справочник по клинической химии / В. Г. Колб, В. С. Камышников. - Минск : Беларусь, 1982. $-311 \mathrm{c}$

17. Меньшиков В. В. Лабораторные методы исследования в клинике : справочник / В. В. Меньшиков, л. Н. Делекторская, Р. П. Золотницкая. - М. : Медицина, 1987. - С. 122, 179-180.

18. Gross D. Ethics in animal-based research / D. Gross, R. Tolba // Eur. Surg. Res. - 2015. - 55, Issue 1-2. - P. 43-57.

19. Okeh U. Statistical problems in medical research. East. Afr. J. Public. Health. - 2009. - 6 (1). - P. 1-7.

20. Хара М. Р. Зміни гліколізу, перекисного окиснення ліпідів та антиоксидантної системи в серці різностатевих щурів з адреналіновою міокардіодистрофрією на тлі блокади холінорецепторів / М. Р. Хара // Мед. хімія. - 2005. - 7, № 1. - С. 21-24. 
21. Штробля А. Л. Стан плазматичних мембран кардіоцитів щурів за умов адреналінового ушкодження міокарду при застосуванні екстракту з листя абрикоса звичайного / А. Л. Штробля, Л. С. Фіра, П. Г. Лихацький // Укр. біофрармац. журн. - 2012. - № 5-6. C. 26-29.

\section{REFERENCES}

1. Rezoliutsiia XVI Natsionalnoho konhresu kardioIohiv Ukrainy (2015). [Resolution of the XVI National Congress of Cardiologists of Ukraine (Kyiv, September 23-25, 2015)]. Ukrayinsikyi kardiolohichnyi zhurnal Ukrainian Cardiology Journal, 5, 126-130 [in Ukrainian].

2. Fushtey, I.M. (2010). Nekotoryye voprosy metabolicheskoy terapii pri ishemicheskoy bolezni serdtsa [Some issues of metabolic therapy in ischemic heart disease]. Suchasni medychni tekhnolohii - Modern Medical Technology, 3, 111-116 [in Russian].

3. Kushakovskiy, M.S. (2000). Metabolicheskiye bolezni serdtsa: (Miokardii-miokardozy-miokardiodistrofiikardiomiopatii) [Metabolic heart diseases: (Myocardialmyocardosis-myocardial dystrophy-cardiomyopathy)]. Saint-Petersburg: Foliant [in Russian].

4. Sumitra, M., Manikandan, P., \& Kumar, D.A. (2001). Experimental myocardial necrosis in rats: role of arjunolic acid on plateled aggregation, coagulation and antioxidant status. Mol. Cell. Biochem.,224 (1-2), 135-142.

5. Markova, O.O. (1998). Miokardiodystrofiia i reaktyvnist orhanizmu [Myocardial dystrophy and reactivity of the organism]. Ternopil: Ukrmedknyha [in Ukrainian].

6. El-Sayed, E.M., Mansour, A.M., \& Abdul-Hameed, M.S. (2015). Thymol and carvacrol prevent doxorubicin-induced cardiotoxicity by abrogation of oxidative stress, inflammation, and apoptosis in rats. J. Biochem. Mol. Toxicol.

7. Kassim, T.A., Clarke, D.D., \& Mai, V.Q. (2008). Catecholamine-induced cardiomyopathy. Endocr. Pract., 14 (9), 1137-1149.

8. Lobo Filho, H.G., Ferreira, N.L., \& Sousa, R.B. (2011). Experimental model of myocardial infarction induced by isoproterenol in rats. Rev. Bras. Cir. Cardiovasc., 26 (3), 232-237.

9. Shtroblia, A.L., Fira, L.S., Vashkeba, E.M., \& Boiko, L.A. (2012). Aktyvnist vilnoradykalnykh protsesiv u shchuriv $v$ umovakh poshkodzhennia miokardu adrenalinom ta pry vykorystanni sukhoho ekstraktu z lystia abrykosa [Activity of free radical processes in rats in conditions of myocardial damage by adrenaline and using dry extract of apricot leaves]. Ukr. biofarm. Zhurnal. - Ukrainian Biopharmaceutical Journal, 4, 94-96 [in Ukrainian].

10. Korsun, V.F., \& Korsun, Ye.V. (2008). Entsiklopediya fitoterapii. Travy zhizni prof. Korsuna [Encyclopedia of herbal medicine. Herbs of life prof. Korsun]. Moscow: ZAO Tsentrpoligraf [in Russian].

11. Gromovaya, V.F., Shapoval, G.S., \& Mironyuk, I.Ye. (2008). Antioksidantnyye svoystva lekarstvennykh ras-
22. Швец В. Н. Содержание адениловых нуклеотидов и компонентов креатинсроссрокиназной системы в сердце взрослых и старых крыс при иммобилизационном стрессе / В. Н. Швец, О. Б. Макоед, Р. Ф. Каптюх // Пробл. старения и долголетия. - 2000. - 9, № 2. - C. 113-116. teniy [Antioxidant properties of medicinal plants]. Khimikofarmatsevticheskiy zhurnal - Chemical-Pharmaceutical Journal, 42 (3), 26-29 [in Russian].

12. Rybolovlev, Yu.R., \& Rybolovlev, R.S. (1979). Dozirovaniye veshchestv dlya mlekopitayushchikh po konstantam biologicheskoy aktivnosti [Dosage of substances for mammals according to biological activity constants]. Doklady AN SSSR - Reports of the USSR Academy of Sciences, 247 (6), 1513-1516 [in Russian].

13. Lushchak, V.I., Bahniukova, T.V., \& Lushchak, O.V. (2004). Pokaznyky oksydatyvnoho stresu. Tiobarbituraktyvni produkty i karbonilni hrupy bilkiv [Indicators of oxidative stress. These compounds are active products and carbonyl groups of proteins]. Ukr. biokhim. Zhurn. Ukrainian Biochemical Journal, 26, 136-141 [in Ukrainian].

14. Chevari, S., Chaba, I., \& Sekey, Y. (1985). Rol superoksiddismutazy $v$ okislitelnykh protsessakh i metod opredeleniya yeye $v$ biologicheskom materiale [The role of superoxide dismutase in oxidative processes and the method of its determination in biological material]. Lab. Delo. - Laboratory Work, 11, 678-681 [in Russian].

15. Mzhelskaya, T.I. (2000). Biologicheskiye funktsii tseruloplazmina i ikh defitsit pri mutatsii genov, reguliruyushchikh obmen medi i zheleza [Biological functions of ceruloplasmin and their deficiency in the mutation of genes regulating the exchange of copper and iron]. Byulleten eksperimentalnoy biologii-Bulletin of Experimental Biology, 130 (8),124-133 [in Russian].

16. Kolb, V.G., \& Kamyshnikov, V.S. (1982). Spravochnik po klinicheskoy khimii [Handbook on Clinical Chemistry]. Minsk: Belarus [in Russian].

17. Menshikov, V.V., Delektorskaya, L.N., \& Zolotnitskaya, R.P. (1987). Laboratornyye metody issledovaniya $\checkmark$ klinike: Spravochnik [Laboratory methods of research in the clinic: Handbook]. Moscow: Meditsina [in Russian].

18. Gross, D., \& Tolba, R. (2015). Ethics in animalbased research. Eur. Surg. Res., 55, (1-2), 43-57.

19. Okeh, U. (2009). Statistical problems in medical research. East. Afr. J. Public. Health., 6 (1), 1-7.

20. Khara, M.R. (2005). Zminy hlikolizu, perekysnoho okysnennia lipidiv ta antyoksydantnoi systemy $v$ sertsi riznostatevykh shchuriv $z$ adrenalinovoiu miokardiodystrofiieiu na tli blokady kholinoretseptoriv [Changes in glycolysis, lipid peroxidation and antioxidant system in the heart of heterozygous rats with adrenal myocardial dystrophy on the background of cholinergic blockade]. Medychna khimiia - Medical Chemistry, 7 (1), 21-24 [in Ukrainian]. 
21. Shtroblia, A.L., Fira, L.S., \& Lykhatskyi, P.H. (2012). Stan plazmatychnykh membran kardiotsytiv shchuriv za umov adrenalinovoho ushkodzhennia miokardu pry zastosuvanni ekstraktu z lystia abrykosa zvychainoho [Condition of plasma membranes of rat cardiocytes in adrenaline damage of myocardium in the application of an extract of apricot leaves ordinary]. Ukr. biofarm. Zhurnal - Ukrainian Biopharmaceutical Journal, 5-6, 26-29 [in Ukrainian].
22. Shvets, V.N., Makoyed, O.B., \& Kaptyukh, R.F. (2000). Soderzhaniye adenilovykh nukleotidov i komponentov kreatinfosfokinaznoy sistemy $v$ sertse vzroslykh i starykh krys pri immobilizatsionnom stresse [The content of adenyl nucleotides and components of the creatine phosphokinase system in the hearts of adults and old rats under immobilization stress]. Probl. stareniya $i$ dolgoletiya - Problems of Aging and Longevity, 9 (2), 113-116 [in Russian].

О. С. Линда, Л. С. Фира, П. Г. Лихацкий ТЕРНОПОЛЬСКИЙ ГОСУДАРСТВЕННЫЙ МЕДИЦИНСКИЙ УНИВЕРСИТЕТ ИМЕНИ И. Я. ГОРБАЧЕВСКОГО

\section{ПРИМЕНЕНИЕ СУХОГО ЭКСТРАКТА ИЗ ЛИСТЬЕВ ХОСТЫ ЛАНЦЕТОЛИСТНОЙ ДЛЯ КОРРЕКЦИИ МЕТАБОЛИЧЕСКИХ НАРУШЕНИЙ В УСЛОВИЯХ АДРЕНАЛИНОВОГО ПОРАЖЕНИЯ МИОКАРДА}

\section{Резюме}

Вступление. Одной из особенностей развития сердечных заболеваний является активация процессов перекисного окисления липидов, увеличение количества прооксидантных процессов, что является следствием воздействия на живую систему гемодинамических нарушений и вызванных ими гипоксических явлений. Для лечения заболеваний сердечно-сосудистой системы используют растительные препараты на основе веществ фрлавоноидной природы, которые имеют широкий спектр активности. Применение лекарственных средств на основе данных веществ обусловлено выраженными антирадикальными свойствами.

Цель исследования - установить антиоксидантные и мембранопротекторные свойства сухого экстракта из листьев хосты ланцетолистной на модели поражения миокарда токсическими дозами адреналина.

Методы исследования. Исследования выполнены на белых крысах-самцах, которым моделировали некротическое повреждение миокарда путем введения 0,18 \% раствора адреналина гидротартрата из расчета 0,5 мг/кг массы тела. Одной из групп животных, пораженных адреналином, вводили сухой экстракт из листьев хосты ланцетолистной в дозе 100 мг/кг массы тела, другой - кардиопротектор корвитин в дозе 42 мг/кг массы тела. В сыворотке крови определяли содержание ТБК-активных продуктов, активность аспартатаминотрансфреразы и креатинфоосфокиназы, активность супероксиддисмутазы и содержание церулоплазмина, в миокарде-содержание ТБК-активных продуктов и вышеназванные органоспецифические энзимы.

Результаты и обсуждение. Установлено, что введение адреналина в дозе 0,5 мг/кг массы тела приводило к активации процессов перекисного окисления липидов в миокарде и сыворотке крови крыс, на что указывало увеличение содержания ТБК-активных продуктов в течение 48 ч от начала эксперимента. Одновременно отмечали снижение в сыворотке крови активности супероксиддисмутазы и повышение содержания церулоплазмина, что свидетельствовало о глубоких нарушениях в энзимном звене антиоксидантной системы. Исследование активности аспартатаминотрансферазы у крыс, пораженных адреналином, показало ее возрастание в сыворотке крови во все сроки исследования и снижение в миокарде. Аналогичные изменения отмечены при изучении активности креатинфосфокиназы у животных после развития адреналиновой кардиопатии. Применение сухого экстракта из листьев хосты ланцетолистной имело эфрфективное влияние на про- и антиоксидантные показатели у крыс после поражения, а также привело к нормализации активности органоспецифических энзимов миокарда.

Вывод. Сухой экстракт из листьев хосты ланцетолистной проявляет антиоксидантные свойства в условиях адреналиновой кардиопатии, что может быть предпосылкой для дальнейших экспериментальных исследований данного лекарственного средства.

КЛЮЧЕВЫЕ СЛОВА: адреналиновое поражение миокарда; сухой экстракт из листьев хосты ланцетолистной; окислительные процессы; антиоксидантная система; органоспецифические энзимы. 


\section{APPLICATION OF EXTRACT FROM HOSTA LONCETOLISTIC FOR CORRECTION OF METABOLIC DISORDERS IN CONDITIONS OF ADRENALINE DISORDER OF MYOCARDIUM}

\section{Summary}

Introduction. One of the features of the development of heart diseases is the activation of lipid peroxidation processes, an increase in the number of prooxidant processes, which is a consequence of the effects on the living system of hemodynamic disorders and the hypoxic phenomena caused by them. For the treatment of diseases of the cardiovascular system, plant preparations are used on the basis of substances of flavonoid nature, which differ in a wide range of activities. The use of drugs based on these substances is due to pronounced antiradical properties.

The aim of the study - to establish antioxidant and membrane protective properties of the dry extract from the leaves of the lanceolithic hosts on the model of myocardial damage by toxic doses of adrenaline.

Research Methods. The studies were performed on white male rats, who were simulated necrotic myocardial damage by administering $0.18 \%$ adrenaline hydrotartrate solution at a rate of $0.5 \mathrm{mg} / \mathrm{kg}$ body weight. One of the groups of animals affected by adrenaline was taken by the extract from the leaves of the hosts at a dose of $100 \mathrm{mg} / \mathrm{kg}$ of body weight, the other - a cardioprotective corvitin at a dose of $42 \mathrm{mg} / \mathrm{kg}$ of body weight. In the blood serum, the content of TBA-active products, activity of aspartateaminotransferase and creatinephosphokinase, superoxide dismutase activity and ceruloplasmin content, in the myocardium - the content of TBA-active products and the above-mentioned organ-specific enzymes were determined.

Results and Discussion. It was found that the administration of epinephrine at a dose of $0.5 \mathrm{mg} / \mathrm{kg}$ of body weight led to the activation of LPO processes in the myocardium and serum of rats, as indicated by an increase in the content of TBA-active products within 48 hours from the start of the experiment. At the same time, there was a decrease in serum of superoxidedismutase activity and an increase in the content of ceruloplasmin, which indicates a profound disturbance in the enzyme link of the antioxidant system. The study of the activity of aspartateaminotransferase in the serum of rats affected by adrenaline showed its increase in all terms of the study and a decrease in the myocardium. Similar changes were noted in the study of the activity of creatinephosphokinase in animals after the development of adrenaline cardiopathy. The use of leaf extract from lanceolitic hosts showed an effective effect on pro and antioxidant indices in rats after injury, and also led to a normalization of the activity of organospecific myocardial enzymes.

Conclusion. Dry leaf extract from lanceolitic hosts showed antioxidant properties under conditions of adrenaline cardiopathy, which may be a prerequisite for further experimental studies of this drug.

KEY WORDS: adrenaline damage to the myocardium; dry extract from leaves hosts; oxidative processes; antioxidant system; organ-specific enzymes.

Адреса для листування: Л. С. Фіра, Тернопільський державний медичний університет імені І. Я. Горбачевського, майдан Волі, 1, тернопіль, 46001, Україна, е-mail: fira@tdmu.edu.ua. 